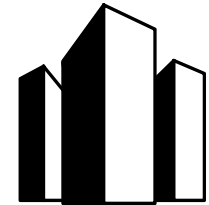

УДК 35.08(430)
Аспекти публічного управління

Aspekty publichnoho upravlinnya

Public administration aspects

Public administration aspects. 2016. 37-38(11-12), 63-69. doi:10.15421/15201663

www.aspects.org.ua

\title{
Community-led local development approach principles implementation when forming a regional local development projects support system in Ukraine
}

\section{Y.G. Udod}

The article contains a brief description of the Community-led local development approach (local development under the leadership of the community, CLLD) and the main purpose of its use in the European Union. The study indicated periods of the major initiatives to support local development in EU. Moreover the article posted CLLD approach principles' evolution and the basic principles of the LEADER method and its application in CLLD, which can be applied in Ukraine. Subject to the provisions of the European Economic and Social Committee (EESC) for further CLLD-approach distribution the five trends were identified that must be considered when forming a Regional local development projects support system in Ukraine: Multi-fund financing; Unification; Networking and collaboration; Extending the approach; Simplifying the process. The characteristic of the present phase of CLLDapproach, in particular, of the European Network for Rural Development (ENRD), which attaches great importance to the dissemination of the most effective CLLD practices and establish partnerships between communities and territories where the approach is implemented. The study found out the relationship between Community-led local development and Community-driven development (CDD) supported by the World Bank.

Keywords: Community-led local development; Community-driven; local development project; CDD approach; CLLD approach підхід; LEADER method

\section{Імплементація принципів підходу community-led local development під час формування регіональної системи підтримки проектів місцевого розвитку в Україні}

\section{Є.Г. Удод²}

У статті подано стислу характеристику підходу Community-led local development (місцевий розвиток під керівництвом громади, CLLD) та основні цілі його застосування в Європейському Союзі. Здійснено періодизацію становлення ініціатив на підтримку місцевого розвитку в ЄС. Подано еволюцію принципів підходу до місцевого розвитку, що керується громадою, і визначено основні принципи методу LEADER $\mathrm{i}$ його імплементації під час реалізації CLLD-підходу, які можна застосувати в Україні. 3 урахуванням положень Свропейського економічного і соціального комітету (EESC) щодо подальшого поширення CLLDпідходу визначено п'ять тенденцій, які необхідно враховувати під час формування регіональної системи підтримки проектів місцевого розвитку в Україні. Надано характеристику сучасному етапу реалізації CLLD-підходу, зокрема, діяльності Європейської мережі розвитку сільських районів (The European network

\footnotetext{
${ }^{1}$ Postgraduate; Dnepropetrovsk regional institute of public administration, the National academy of public administration under the President of Ukraine, 29, Gogol Str., Dnipro, 49044, Ukraine

${ }^{2}$ Аспірант; Дніпропетровський регіональний інститут державного управління Національної академії державного управління при Президентові України, 49044, Дніпро, вул. Гоголя, 29

${ }^{3}$ Аспирант; Днепропетровский региональный институт государственного управления Наџиональной академии государственного управления при Президенте Украины, 49044, Днепр, ул. Гоголя, 29
} 
for rural development, ENRD), що приділяє велику увагу поширенню найбільш ефективних практик CLLD i встановленню партнерських відносин між громадами та територіями, де підхід реалізується. Встановлено зв'язок між підходами Community-led local development та Community-driven development (місцевий розвиток за ініціативи громади, CDD), що підтримується Світовим банком.

Ключові слова: місцевий розвиток за ініціативи громади; місцевий розвиток під керівництвом громади; проект місцевого розвитку; CDD-підхід; CLLD-підхід; LEADER-метод

\section{Имплементация принципов подхода community-led local development в ходе формирования региональной системы поддержки проектов местного развития в Украине}

\section{Е.Г. Удод ${ }^{3}$}

В статье представлено краткую характеристику подхода Community-led local development (местное развитие под руководством общины, CLLD) и основные цели его применения в Европейском Союзе. Осуществлено периодизацию становления инициатив в поддержку местного развития в ЕС. Представлено эволюцию принципов подхода по местному развитию под руководством общины и определены основные принципы LEADER-метода и его имплементации в ходе реализации CLLD-подхода, которые можно применить в Украине. С учетом рекомендаций Европейского экономического и социального комитета (EESC) по дальнейшему расширению применения CLLD-подхода определено пять тенденций, которые необходимо учитывать в ходе формирования региональной системы поддержки проектов местного развития в Украине. Представлено характеристику современного этапа реализации подхода, в том числе деятельности Европейской сети развития сельских территорий (The European network for rural development, ENRD), которая уделяет значительное внимание распространению наиболее эффективных практик CLLD и установлению партнерских взаимоотношений между общинами и территориями, где подход реализуется. Установлено взаимосвязь между подходами Community-led local development и Community-driven development (местное развитие, инициируемое общиной), который поддерживается Мировым банком.

Ключевые слова: местное развитие; инициируемое общиной; местное развитие под руководством общины; проект местного развития; CDD-підхід; CLLD-підхід; LEADER-метод

Peer-reviewed, approved and placed: 15.10 .2016

The problem formulation. In the second decade of the 21 st century the Community-led local development approach is spreading gradually. Community-led local development, CLLD - a term used to describe the European Commission approach that expands the traditional - «top-down» policy development in the opposite direction [2]. In terms CLLD, residents take «the reins» and form a local partnership, which develops and implements integrated development strategy. The strategy is being developed to reinforce the social, environmental and economic benefits community or «assets», but only the compensation of their own problems. For this partnership receives long-term funding. And those participants decide how to spend it.

In policy documents of the European Commission on «Cohesion Policy 2014-2020» states that is not accidental that the application of the principles CLLD spread over the last twenty years, a small cluster of 200 pilot projects «LEADER» in more than 2600 partnerships covering almost every part of the «village Europe» and a significant part of the coast [4-6]. Total public and private investment to support these partnerships also rose to around EUR 8.6 billion for the period 2007-2013, supporting a wide range of mostly smaller projects, thousands of companies and jobs, and a significant improvement of local services and the environment.

CLLD-Principles not only fixed but also multiplied more than tenfold during four consecutive periods of financing. This experience has shown, and when and where CLLD-approach works properly, and how partnerships can add value to national and regional programs. It was also shown CLLD's limitations and found areas where difficult to achieve results. In this context, there is a great opportunity to spread CLLD approach to the Ukrainian communities and use it to develop local responses to some of the most pressing social and environmental problems facing Ukrainian amalgamated communities today. In addition, there are significant opportunities to increase CLLD impact on the lives of citizens by coordinating four main streams of funding from 
the European Union and EU partner-communities.

The research and publications' analysis. The main provisions of the CLLD approach set out in the policy documents the European Commission on «Cohesion Policy 2014-2020» [4-6].

The expert group headed by Marjorie Jouen and Katalin Kolosy in the "Cohesion policy support for local development: best practice and future policy options») (2010) allowed to formulating comprehensive recommendations for local development best practice and policy options for support to local development initiatives within the cohesion policy [8].

In «Local development in Europe: Assessment and prospects after the economic crisis» (2011) Marjorie Jouen specified that ehe best solution today seems to consist of a better coordination of existing local-development programmes at European level, together with stronger encouragement for ERDF and ESF intervention in the form of a compulsory minimal allocation in regional development programmes, along with methodological support [7].

The European Funding Network publication «Community Led Local Development - An essential element in the delivery of the new European Structural Funds» (2012) presented particular: the roots of CLLD, CLLD achievements and limitations, evidence and implications for the New Programme and some Case studies [3].

At the paper «Preliminary Draft Opinion of the Section for Economic and Monetary Union and Economic and Social Cohesion on Community Led Local Development as a tool of Cohesion Policy 2014-2020 for local, rural, urban and peri-urban development» (2014) Roman Haken summarized the role of Local Action Groups in the 2014-2020 programming period and put forward some recommendations for implementing CLLD in the rural, peri-urban and urban environment [9]. Thus, the authors in previous publications and policy documents at scientificcommunication activities offered scientific basis for choosing methods and tools to be applied during the formation and development of the CLLD approach in EU-countries. With this in mind, the purposes of the article are: to provide a brief description of the CLLD approach; to indicate periods of the major initiatives to support local development in EU; to post CLLD approach principles' evolution and the basic principles of the LEADER method and its application in CLLD, which can be applied in Ukraine; to identify trends that must be considered when forming a regional system to support local development projects in Ukraine; to characterize the present phase of the CLLD approach implementation; to find out the relationship between Community-led local development and Community-driven development supported by the World Bank.

The main material presentation. The new rules and legislation governing the next round of EU Cohesion Policy investment for 2014-2020 have been formally endorsed by the Council of the European Union in December 2013. The main are CLLD-identifying and its objectives.

Community-led Local Development (CLLD):

- is a single methodology regarding CLLD for the ESI Funds (The European structural and investment funds), which focuses on specific sub-regional area; is community-led, by local action groups composed of representatives of local public and private socio-economic interests;

- is carried out through integrated and multisectoral area-based local development strategies, designed taking into consideration local needs and potential;

- takes into consideration local needs and potential, includes innovative features in the local context, networking and, where appropriate, co-operation [5].

The main aims of this joint approach by the ESI Funds are to simplify and expand the use of CLLD as a development tool. The CLLD will:

- encourage local communities to develop integrated bottom-up approaches in circumstances where there is a need to respond to territorial and local challenges calling for structural change;

- build community capacity and stimulate innovation (including social innovation), entrepreneurship and capacity for change by encouraging the development and discovery of untapped potential from within communities and territories;

- promote community ownership by increasing participation within communities and build the sense of involvement and ownership that can increase the effectiveness of EU policies;

- assist multi-level governance by providing a route for local communities to fully take part in shaping the implementation of EU objectives in all areas [5]. 
The expert group headed by Marjorie Jouen and Katalin Kolosy in the «Cohesion policy support for local development: best practice and future policy options» (2010) defined two phases of development of the initiatives (Table 1). Especially should be noted the impact of the program LEADER [8]. «LEADER» (a French acronym for «Links between actions for the development of agriculture») - an initiative of the European Union in support of rural development projects, initiated at the local level for rural areas revival and create jobs (LEADER I (1991-93), LEADER II (1994-99), LEADER + - the third phase of the initiative (2000-2006)).

Through the technical expertise provided un- der the LEADER initiative, the grounds for testing a robust theoretical basis were gathered and led to the identification of a specific set of local development features. In LEADER I, four principles were identified [8]:

1. ACTIONS: Area-based approach; Bottomup; Innovation, integrated, multi-sectoral character.

2. PARTNERSHIP: Horizontal (Local Action Groups); Vertical (implementation procedures by the public administrations involved).

3. FINANCING: The global grant.

4. NETWORKING: The European network \& Coordination Unit; Other networking practices.

Table 1. The phases and stages of major initiatives to support local development (LD)

\begin{tabular}{|c|c|c|c|}
\hline Phase / stage & Term & Pilot programs & $\begin{array}{l}\text { LD-programs' } \\
\text { main focus }\end{array}$ \\
\hline \begin{tabular}{|l|l|} 
I. From spontaneous \\
generation to cultivation
\end{tabular} & $1980-1990$ & & \\
\hline $\begin{array}{l}\text { 1.1. Exploration - before } \\
\text { the cohesion policy }\end{array}$ & to 1988 & $\begin{array}{l}\text { Integrated Mediterranean pro } \\
\text {-grammes, OECD (before LEED), } \\
\text { contrats de ville (FR) }\end{array}$ & Initiatives not yet programmes \\
\hline \multirow[t]{3}{*}{$\begin{array}{l}\text { 1.2. Discovery of the local } \\
\text { endogenous potential and } \\
\text { «make-of» theory }\end{array}$} & 1989-1993 & $\begin{array}{l}\text { ILE, LEADER, social coopera } \\
\text {-tives (IT), Poverty III }\end{array}$ & $\begin{array}{l}\text { Economic regeneration in } \\
\text { rural or urban areas, SMEs } \\
\text { incubators or nurseries, } \\
\text { innovative «milieu» }\end{array}$ \\
\hline & 1994-1996 & $\begin{array}{llr}\text { Area partnerships } & \text { (IRL), } \\
\text { «Programme intégré } & \text { de } \\
\text { développement local» (PT), } \\
\text { «Plans locaux d'insertion par } \\
\text { l'économique» (FR), "contrats de } \\
\text { terroir» (FR) and "Plateformes } \\
\text { d'initiative locale» (FR), Melkert } \\
\text { Plan - REWLW (NL), Labour } \\
\text { Foundations (AT), RITTS, } \\
\text { RECITE, PEACE }\end{array}$ & $\begin{array}{l}\text { Partnership, skills engineering, } \\
\text { global grant, «animation» }\end{array}$ \\
\hline & 1996-1999 & $\begin{array}{l}\text { URBAN, INTEGRA, B-2605 } \\
\text { (long-term } \\
\text { Territorial Employment Pacts, } \\
\text { «PRODER» (ES), «Inclusion of } \\
\text { Refugees Programme» (SW), } \\
\text { POMO (FIN), UK: "Single } \\
\text { regeneration budget» and "City } \\
\text { Challenge» }\end{array}$ & $\begin{array}{l}\text { Employment, new sources of } \\
\text { jobs (every sector explored), } \\
\text { social economy, intermediate } \\
\text { labour market }\end{array}$ \\
\hline \begin{tabular}{|l|} 
II. Separate policies and \\
gradual disappearance
\end{tabular} & 2000-today & $\begin{array}{l}\text { Integrated programmes } \\
\text { cofinanced by the ERDF, the } \\
\text { ESF and the EAGGF Guidance } \\
\text { Section; The EQUAL programme; } \\
\text { INTEGRA; URBAN; ISPA; } \\
\text { URBACT }\end{array}$ & $\begin{array}{l}\text { Rural development; } \\
\text { employment, equal } \\
\text { opportunities and social } \\
\text { inclusion; } \\
\text { economic and social cohesion, } \\
\text { regional policy }\end{array}$ \\
\hline
\end{tabular}


In LEADER II, the another matrix was adopted to illustrate the LEADER method endorsed by Local Action Groups (LAGs). The «Inter-territorial cooperation» and «Decentralized management and financing» principals were added.

Fundamental principles of the LEADER method and its application in CLLD for 20132020 are given in Table 2.

Roman Haken (2014) specifies at the paper «Preliminary Draft Opinion of the Section for Economic and Monetary Union and Economic and Social Cohesion on Community Led Local Development as a tool of Cohesion Policy 2014-2020 for local, rural, urban and peri-urban development» [9] that the LEADER approach has demonstrated its viability over the past twenty years. It has helped rural actors assess the long-term potential of their local regions and proven an effective and efficient tool in the delivery of development policies. The European Commission has used the Community Initiatives
URBAN and EQUAL, among other things, to promote this partnership-based method of funding projects. This is what gave rise to Community Led Local Development (CLLD), which is, in a way, a transitional change. CLLD is a dedicated tool for use at sub-regional level and thus complements other development support at local level. It has the capacity to mobilize and involve local communities and organizations so they can contribute to achieving the Europe 2020 strategy goals of smart, sustainable and inclusive growth It also fosters territorial cohesion and enables particular policy objectives to be attained. The fact that Member States have incorporated CLLD into their partnership agreements is proof of how important local development is now considered.Subject to the provisions of the European Economic and Social Committee (EESC) for further CLLD-approach distribution [9] when forming the Regional local development projects support system in Ukraine the following five trends are advisable to consider:

Table 2. Fundamental principles of the LEADER method and its application in CLLD

\begin{tabular}{|c|c|}
\hline Principle & Comment \\
\hline 1. The area-based approach & $\begin{array}{l}\text { The programme uses the real potential of small defined areas to } \\
\text { promote their sustainable development. It takes on board their } \\
\text { pluses and minuses and produces a development strategy that } \\
\text { matches their real needs. The confines of an area are not established } \\
\text { solely by administrative borders and are elastic }\end{array}$ \\
\hline 2. The bottom-up approach & $\begin{array}{l}\text { In deciding on and setting development strategy priorities we } \\
\text { place great emphasis on involving local administration and the } \\
\text { public. The stress on the lowest level is the most important of the } \\
\text { programme's seven points. In this, however, the programme is not } \\
\text { seeking to take the place of the higher - national - tier, but merely } \\
\text { to foster communication between these two strata }\end{array}$ \\
\hline 3. The Local Action Group & $\begin{array}{l}\text { One important facet of the programme is to lend help in setting } \\
\text { up Local Action Groups. The purpose of these groups is to link } \\
\text { partners from the public, private and voluntary spheres and prompt } \\
\text { dialogue about what direction the area's development should take }\end{array}$ \\
\hline 4. The innovative approach & $\begin{array}{l}\text { The programme supports innovation. It endeavours to create new } \\
\text { products, processes, organisations and markets. The way to achieve } \\
\text { innovation is to give the Local Action Groups the greatest possible } \\
\text { room for manoeuvre }\end{array}$ \\
\hline 5. An integrated and multi-sectoral approach & $\begin{array}{l}\text { The programme's approach lays stress on the integration of various } \\
\text { sectors. It seeks to dovetail the economic, social, cultural and } \\
\text { environmental dimensions and integrate them into comprehensive } \\
\text { projects }\end{array}$ \\
\hline 6. Networking & $\begin{array}{l}\text { The programme foregrounds the creation of networks to pool } \\
\text { experience among its participants. These networks are both } \\
\text { institutional (funded by the European Commission) and less } \\
\text { formal: national, regional and local }\end{array}$ \\
\hline
\end{tabular}


1. Multi-fund financing - monitoring and strengthening the CLLD approach within multifund financing across Europe and in EU programmes and working to launch the next programming period as quickly as possible.

2. Unification - unifying the quality of CLLD in the EU, standardizing LAG procedures and pooling best practice; lending support for filling in gaps on the map so that the LEADER approach can be extended geographically and thematically, which is necessary if the LEADER/ CLLD approach is to operate successfully within various EU programmes.

3. Networking and collaboration - an essential condition for the CLLD approach to work well; implementation of cooperation projects and a stress on the need for networking at regional, national and European level and the need for expenditure on networking to be eligible, including the contributions made by members.

4. Extending the approach - supporting the use of the CLLD method beyond Europe, for example in pre-accession negotiations and development policy.

5. Simplifying the process - making sure these small entities at local level are not engulfed in excessive red tape; where possible, reducing reporting requirements to the minimum reliable level.

At the present stage of development focus within the implementation of the integrated approach LEADER / CLLD is paid for Transnational and inter-territorial cooperation and Umbrella Projects, which have become increasingly important for rural stakeholders. Substantial experience gathered during previous generations of LEADER demonstrate that cooperation is an effective mechanism for helping rural areas to jointly develop and share new solutions to common issues.

LEADER cooperation involves networking but on a different, more dynamic level. It encourages and supports Local Action Groups (LAGs) to undertake a joint action with another LEADER group, or with a group taking a similar approach, in another region or Member State, with an urban or fisheries area or even with a rural group in a third country. The general objective of LEADER cooperation is to help local actors to improve the potential of their areas.

The European network for rural development (ENRD) pays great attention to the best practices' dissemination and the establishment of the CLLD partnerships. In particular ENRD implemented communication activities for stakeholders continuously.

At the beginning of 2016 the ENRD Contact Point organized a workshop on «Umbrella Projects in LEADER/CLLD» to provide a platform for exchange on the opportunities and challenges of umbrella projects under LEADER/CLLD between Managing Authorities and with European Commission representatives. The workshop was organized in response to a request from a group of Managing Authorities (MAs) from Austria, Germany, Luxembourg and Sweden who are already working on this issue. It gathered more than 20 participants from 11 Member States, as well as European Commission Officials, including DG AGRI auditors [10].

On December 2016 the two-day seminar was focused on how to make the best possible use of the Community-Led Local Development (CLLD) method supported under Rural Development (EAFRD), Fisheries (EMFF), Regional Development (ERDF) and Social (ESF) Funds [1].

The event brought together Local Action Groups and other local actors, Managing Authorities and National Networks from across the four ESI Funds. It enabled mutual learning through exchange of practical experience in implementing the CLLD method and a field visit to local projects. It was the second in a series of seminars organised jointly by the four EU Commission Directorates General managing the ESI Funds and supporting CLLD. In 2016 event was hosted by the Swedish MA and Network Support Unit, along with DG AGRI and the ENRD Contact Point.

The ENRD web-site contains materials of all seminars, including presentations and Overview of the financial allocations and implementation of CLLD in Europe and under each of the European Structural and Investment Funds (ESIFunds): Rural Development (EAFRD), Fisheries (EMFF), Regional Development (ERDF) and Social (ESF) [1].

Outside of Europe, the World Bank supports projects using a similar methodology - community «driven» development.

Community-driven development (CDD) is an approach that emphasises community control over planning decisions and investment resources. A rigorous evaluation process helps determine CDD's effectiveness in various settings and highlights areas that need strengthening for 
second-phase programs or new projects. The note «Social Development Notes - Community Driven Development» (2013) of the World Bank [11] summarized the findings of a study entitled "What have been the impacts of World Bank Community-Driven Development Programs?».

This study pointed that the CDD is an approach that gives communities control over the planning, investment, and management decisions for local development activities. The philosophy behind CDD is that involving communities in these decisions often leads to the better use of resources geared toward meeting the most pressing needs. This «bottom-up» approach has become a key operational strategy for many national governments and international aid agencies for the delivery of services, improvement of livelihoods, and empowerment of people. The World Bank currently supports approximately 400 CDD projects in more than 90 countries, valued at almost US $\$ 30$ billion.1 Over the past decade, CDD investments have represented between 5 and 10 percent of the overall annual Bank lending portfolio. Although the design of these programs has evolved over time, at their core, most of these programs aim to improve the living con- ditions of poor communities through increased participation [11].

Conclusions. In our opinion, the greatest impact of these trends carry the following elements of the specified Regional local development projects support system: a network of resource centers; subsystem of local government and self-organization involvement to participate in local development projects' awards at various levels; stakeholders management subsystem, that insert donor agreements' complex; specialized Internet resource with a platform for the communities of practice's formation.

Areas for further research and practical implementation of research results:

1. Scientific substantiation of the CLLD-approach implementation mechanisms and sources of funding in Ukraine.

2. Special curriculum in CLLD and CDD development for civil servants, local councilors, local government officials and NGOs representatives at the centers of retraining and advanced training in Ukraine.

3. Scientific support and technical support for a regional community of practices in local development (on a specialized online platform).

\section{REFERENCES:}

1. Achieving Results the CLLD Way: Putting the Method to Work, 2016 (Båstad, Sweden, Transnational CLLD Seminar, December 6-8, 2016). Access: http://enrd.ec.europa.eu/news-events/events/achieving-results-clld-way-putting-methodwork_en

2. Community-Led Local Development (CLLD). The European network for rural development (ENRD). Access: https:// enrd.ec.europa.eu/themes/clld en

3. Community Led Local Development - An essential element in the delivery of the new European Structural Funds, 2012 (European Funding Network, NCVO, October, 2012). Access: http://vcsvoice.org/wp-content/uploads/2013/08/CommunityLed-Local-Development-NCVO.pdf

4. Integrated territorial investment. Cohesion Policy 2014-2020, 2014 (Brussels, European Commission, March 2014). Access: http://ec.europa.eu/regional policy/sources/docgener/informat/2014/iti en.pdf

5. Community-LED Local Development. Cohesion Policy 2014-2020, 2014 (Brussels, European Commission, March 2014). Access: http://ec.europa.eu/regional policy/sources/docgener/informat/2014/community en.pdf

6. Guidance on Community-Led Local Development for Local Actors, 2014 (Brussels, European Commission, Version 1: May 2014). Access: http://ec.europa.eu/regional_policy/sources/docgener/informat/2014/guidance_clld_local_actors.pdf 7. Jouen, M. Local development in Europe: Assessment and prospects after the economic crisis Notre Europe, 2011. Policy Brief, Notre Europe 21 (January), 6. Access: http://www.institutdelors.eu/media/bref21-mj-en.pdf?pdf=ok

8. Jouen M., Kolosy K., Pellegrin J.-P., Ramsden, P., Szegvari P., Chambon N., 2010. Cohesion policy support for local development: best practice and future policy options (DG REGIOCCIn.2009.CE.16.0.AT.081). Access: http://ec.europa.eu/ regional_policy/archive/consultation/terco/cp_support_local_dev_en.pdf

9. Haken, R. 2014. Preliminary Draft Opinion of the Section for Economic and Monetary Union and Economic and Social Cohesion on Community Led Local Development (CLLD) as a tool of Cohesion Policy 2014-2020 for local, rural, urban and peri-urban development (exploratory opinion at the request of the Greek Council presidency). (Brussels, European Economic and Social Committee, 22 September 2014, ECO/366 CLLD). - Access: http://www.aeidl.eu/images/stories/pdf/clld-eesc.pdf 10. Umbrella Projects in LEADER/CLLD, 2016 (Brussels, ENRD workshop, 15 February 2016). Access: http://enrd. ec.europa.eu/news-events/events/enrd-workshop-\%E2\%80\%98umbrella-projects-leaderclld\%E2\%80\%99_en

11. What Have Been the Impacts of World Bank CDD Program? Operational and Research Implications, 2013. Social Development Notes. Community Driven Development, 136 (Fabuary 2013). The World Bank, Social Development Department. Access: http://enrd.ec.europa.eu/sites/enrd/files/assets/pdf/clld/ReviewImpactsCDD-World-Bank_en.pdf 